\title{
Effect of hydrochemical ion pair CaCO30 on the deposition of travertine from the Heinitang hot springs in Yunnan of China
}

\author{
Haisheng Liu ${ }^{1}$, Xun Zhou ${ }^{2}$, Mengmeng Wang ${ }^{1}$, Yu Liu ${ }^{1}$, and Hongfei Xu ${ }^{1}$ \\ ${ }^{1}$ China University of Geosciences Beijing School of Water Resources and Environment \\ ${ }^{2}$ China University of Geosciences
}

August 17, 2020

\begin{abstract}
The Heinitang hot spring is located in the western Yunnan of China and lies in the Tibet-Yunnan geothermal zone and the Tengchong Block. The hot water is of $\mathrm{HCO} 3-\mathrm{Ca}^{*} \mathrm{Na}$ type and the $\mathrm{F}$ concentration is relatively high (ranging from 3.8 to 5 $\mathrm{mg} / \mathrm{L}$ ). Fossil travertine mounds and cones and new travertine are found at the spring vents. Hydrochemical analyses indicate that the primary factor affecting the deposition of travertine is the concentration of ion pair CaCO30 in the Heinitang hot springs. The Heinitang hot spring shows a positive correlation between the concentration of CaCO30 and the saturation index with respect to aragonite, calcite and dolomite. They are not linearly related, but have an exponential relationship. When the aragonite, calcite and dolomite are in the state of dissolved equilibrium, the corresponding concentrations of CaCO30 are $0.01 \mathrm{mmol} / \mathrm{L}, 0.008 \mathrm{mmol} / \mathrm{L}$ and $0.012 \mathrm{mmol} / \mathrm{L}$, respectively, indicating that the precipitation of travertine can occur when the concentration of $\mathrm{CaCO} 30$ is higher than $0.008 \mathrm{mmol} / \mathrm{L}$. In addition, the concentrations of CaCO30 in the Heinitang hot springs decrease gradually with the deposition of travertine. The precipitation of travertine cannot occur when the concentration of CaCO30 decreases to lower than $0.008 \mathrm{mmol} / \mathrm{L}$.
\end{abstract}

\begin{abstract}
The Heinitang hot spring is located in the western Yunnan of China and lies in the Tibet-Yunnan geothermal zone and the Tengchong Block. The hot water is of $\mathrm{HCO}_{3}-\mathrm{Ca}^{*} \mathrm{Na}$ type and the $\mathrm{F}$ concentration is relatively high (ranging from 3.8 to $5 \mathrm{mg} / \mathrm{L}$ ). Fossil travertine mounds and cones and new travertine are found at the spring vents. Hydrochemical analyses indicate that the primary factor affecting the deposition of travertine is the concentration of ion pair $\mathrm{CaCO}_{3}{ }^{0}$ in the Heinitang hot springs. The Heinitang hot spring shows a positive correlation between the concentration of $\mathrm{CaCO}_{3}{ }^{0}$ and the saturation index with respect to aragonite, calcite and dolomite. They are not linearly related, but have an exponential relationship. When the aragonite, calcite and dolomite are in the state of dissolved equilibrium, the corresponding concentrations of $\mathrm{CaCO}_{3}{ }^{0}$ are $0.01 \mathrm{mmol} / \mathrm{L}, 0.008 \mathrm{mmol} / \mathrm{L}$ and $0.012 \mathrm{mmol} / \mathrm{L}$, respectively, indicating that the precipitation of travertine can occur when the concentration of $\mathrm{CaCO}_{3}{ }^{0}$ is higher than $0.008 \mathrm{mmol} / \mathrm{L}$. In addition, the concentrations of $\mathrm{CaCO}_{3}{ }^{0}$ in the Heinitang hot springs decrease gradually with the deposition of travertine. The precipitation of travertine cannot occur when the concentration of $\mathrm{CaCO}_{3}{ }^{0}$ decreases to lower than $0.008 \mathrm{mmol} / \mathrm{L}$.
\end{abstract}

Keywords: hot springs; travertine; hydrochemistry; $\mathrm{CaCO}_{3}{ }^{0}$; Yunnan;

\section{Introduction}

The terms "travertine" and "tufa", in its broadest sense, refer to non-marine carbonate precipitates near springs, rivers, lakes and caves, which consist of calcite or aragonite (Viles and Goudie, 1990; Pentecost, 2005). Tufa is the precipitation of calcium carbonate under cool water (near ambient temperature) and 
travertines are calcareous deposits that precipitate where thermal groundwaters emerge at springs (Ford and Pedley, 1996; Li and Robert, 1998; Fedoseev et al., 2017). Tufa or travertine can provide valuable information to study the paleo-climate and paleo-environment (Chafetz et al., 1991; Fouke et al., 2000) and have implications for hydrogeological evolution history and present or past fluid dynamic regimes (Andreo et al., 1999; Naroa et al., 2018). Travertine may reflect changes in temperature and rainfall by changing isotopic compositions, minerals, the rate of growth and texture. In addition, travertine have various applications in construction, agriculture, decorative arts, etc. (Erdoğan, 2011).

Travertine deposits form by important precipitation of carbonates and are distributed over the world (Pentecost, 1995a). However, the precipitation of travertine only occurs near a small portion of hot springs (Zhou et al., 2017). Travertine deposits are formed when thermal groundwater, rich in $\mathrm{Ca}, \mathrm{HCO}_{3}$ and $\mathrm{CO}_{2}$, flows to the surface and outgases $\mathrm{CO}_{2}$ to the atmosphere. Re-equilibration of $\mathrm{CO}_{2}$ in groundwater can result in saturation of $\mathrm{CaCO}_{3}$ and travertine deposits downstream from the hot spring (Pentecost, 1999; Acikel and Ekmekci, 2016). Therefore, it is significant to study the hydrochemical characteristics of hot springs to better understand the factors affecting the precipitation of travertines. Interest in the travertine-depositing hot springs has increased and the studies of hydrochemical characteristics of hot springs have attracted attention since the 19th century. In the travertine-depositing hot springs, the concentrations of major and trace elements were determined by numerous researchers. The characteristics of hydrochemical compositions in travertine-depositing hot springs in Italy are high concentrations of $\mathrm{CO}_{2}, \mathrm{Ca}, \mathrm{Mg}$ and $\mathrm{SO}_{4}$ (Pentecost, 1995b). The Pamukkale hot springs in Turkey contain high concentrations of $\mathrm{HCO}_{3}, \mathrm{Ca}$ and $\mathrm{SO}_{4}$ in the ranges from 1100 to $1300 \mathrm{mg} / \mathrm{L}$, from 400 to $500 \mathrm{mg} / \mathrm{L}$ and from 600 to $750 \mathrm{mg} / \mathrm{L}$, respectively (Yesertener and Elhatip, 1997). Kawai et al. (2009) proposed that the precipitation rate of $\mathrm{CaCO}_{3}$ is mainly controlled by $\mathrm{Ca}$ and alkalinity, which is relatively low when Ca concentrations are less than $65 \mathrm{mg} / \mathrm{L}$. However, the precipitations of travertine from the Jifei hot spring in western Yunnan of China took place on a cliff face when the concentration of Ca is $58.1 \mathrm{mg} / \mathrm{L}$ (Liu et al., 2012; Jones and Peng, 2016). The high concentrations of $\mathrm{Ca}$ and $\mathrm{Mg}$ of hot springs can arise apparently saturation with respect to calcite and aragonite when the thermal groundwater rises to the surface with the $\mathrm{CO}_{2}$-outgassing. In addition, other hydrochemical factors proposed as influential in the precipitation of travertine from hot springs include the saturation index with respect to carbonate (Dandurand et al., 1982), hydrochemical type (Dilsiz et al., 2004), temperature and pH (Veysey et al., 2008) and the relationship between major elements (Kele et al., 2008). The hydrochemical type and saturation index with respect to calcite are common indications in the analyses of the travertinedepositing hot springs. The Pamukkale travertine-depositing hot springs exhibited a $\mathrm{HCO}_{3}{ }^{*} \mathrm{SO}_{4}$-Ca type and positive values of saturation index calculated with Phreeqc-2 (Dilsiz, 2006). Fouke (2011) established a quantitative correlation among the temperature, $\mathrm{pH}$ and flux and classically-defined travertine depositional facies at the Mammoth hot springs in the Yellowstone National Park. Kele et al. (2011) suggested that the Jandarma hot spring in Turkey show a positive correlation between the equivalent concentrations of Ca and $\mathrm{HCO}_{3}$ and the values of $\gamma \mathrm{Ca} / \gamma \mathrm{HCO}_{3}$ range from 1.5 to 1.8. Wang et al. (2015) noted that the concentrations of $\mathrm{Ca}$ and $\mathrm{HCO}_{3}$ decrease gradually along the path of travertine deposition at the Lianchangping hot springs in western Yunnan of China and the values of $\gamma \mathrm{Ca} / \gamma \mathrm{HCO}_{3}$ are almost constant (nearly 1). Frery et al. (2017) noted that the precipitation of travertine takes place near the outlet of the hot springs that represent the chemical characteristics of high $\mathrm{PCO}_{2}$ values and saturation index (SI) values with respect to carbonate minerals. However, there is limited data on the influence of $\mathrm{CaCO}_{3}{ }^{0}$ ions pairs on travertine deposition from hot springs.

It seems that further research is needed to interpret the hydrochemical factors affecting the deposition of travertine. So far, substantial papers to clarify this matter have been published. In the present paper, we examine 8 water samples collected at the Heinitang hot springs in western Yunnan of China in 2013 and 2018 during field investigations where travertines are depositing from the hot springs. This paper places its emphasis on a new hydrochemical factor affecting the deposition of travertine from the Heinitang hot springs by analyzing the concentrations of $\mathrm{CaCO}_{3}{ }^{0}$ and establish the relationship between the concentrations of $\mathrm{CaCO}_{3}{ }^{0}$ and the saturation index with respect to aragonite, calcite and dolomite that other researchers have not done. 


\section{Location and geological setting}

The Heinitang hot spring is located some $6 \mathrm{~km}$ to the northwest of the Houqiao town near Tengchong in western Yunnan. Tengchong is situated at the border area of southwestern China (Fig. 1).

Fig. 1. The location of Yunnan and Tengchong (Adapted from National Geomatics center of China)

The Tengchong area lies in the Tengchong Block (Fig. 2a), where the magmatism and volcanic activities occurred frequently and many hot springs exist.

The field site for this study lies in the northwest of Tengchong in Yunnan, which is underlain by Paleogene, Triassic, Permian, Devonian and Proterozoic rocks. Lithologically, the Paleogene rocks are composed of moyites. The Triassic rocks appear mainly in the west of the area and consist of monzonitic granite. The Permian rocks consist of slates, sandstones and quart arenites. The Devonian rocks consist of argillic and carbonaceous slates and high permeability limestones. The Proterozoic rocks consist of mica schist, plagiogneiss, quartzites and granulites of low permeability (Fig. 2b).

The Heinitang hot spring is located at the western edge of the Permian rocks and it is structurally controlled by a NW-SE fault. The Heinitang hot spring includes of 7 vents (S1, S2, S3, S4, S5, S6 and S7) (Fig. 3). The temperature of the hot water ranges from 50.9 to 66.6 . In addition, there are several fossil travertine mounds and cones near the hot spring vents. The travertine mounds and cones were weathered to some degree. The travertine cones range in height from $0.3 \mathrm{~m}$ to $5.5 \mathrm{~m}$ (Fig. 3). Apparent change in morphologies from travertine mounds to travertine cones indicate that the discharge of the Heinitang hot springs decreased with time in the past. In recent decades, the hot water was used for bathing by constructing pools near vents S2, S3 and S4. New travertine deposits near these pools as a result of outflow of hot water from the pools. The C8 travertine cone is relatively well preserved (Fig. 4a). Travertine deposited near vent S2 in 2018 (Fig. 4c) are obviously larger than that in 2013 (Fig. 4b). Small scales of travertine are depositing near vent S1, but in 2013 no travertine was found to deposit near this vent.

Fig 2. (a) Simplified tectonic map of the western Yunnan (Adapted from Bureau of Geology and Mineral Resources of Yunnan Province) and (b) the location of the Heinitang hot spring (Adapted from Bureau of Geology and Mineral Resources of Yunnan Province, 1990) 1 Paleogene Moyites; 2 Triassic Monzonitic granit; 3 Sandstones of the Permian; 4 Devonian Argillic and carbonaceous slates; 5 Proterozoic Quartzites.

Fig. 3. Plan diagram and profile of the Heinitang hot springs with 2 travertine mounds and 14 cones. (The number is the height of the inactive travertine cone $(\mathrm{m}))$.

Fig. 4. Field photographs of travertines: (a) The inactive travertine cone (C8); (b) Travetines near vent S2 in 2013 and (c) Travertines near S2 in 2018.

\section{Materials and methods}

\section{Field sampling and measurements}

Field works at Heinitang were carried out in August 2013 and March 2018. Two water samples (S2* and $\mathrm{S}^{*}$ ) were collected in 2013 and another six water samples (S1, S2, S3, S4, S5 and S6) were collected in 2018. S7 could not be collected since it was surrounded by mud. The water samples were collected as close to the vents as possible. Water samples for chemical and isotopic analyses were collected in $550 \mathrm{ml}$ glass bottles which were water-rinsed at least 3 times prior to field sampling. The water samples were sent to the laboratory as soon as possible.

In situ measurements of some physicochemical characteristics of hot springs were completed at all the sampling points. Water samples were measured for free carbon dioxide $\left(\mathrm{CO}_{2}\right)$, temperature, $\mathrm{pH}$ and Eh in the field (Table 1). The temperatures of water samples were determined with a MIK-TP101 thermometer. The values of $\mathrm{pH}$ and $\mathrm{Eh}$ were determined in situ using a CT-6821 $\mathrm{pH}$ meter. The concentrations of $\mathrm{CO}_{2}$ 
were measured by $\mathrm{NaOH}-\mathrm{HCl}$ titration in situ using digital titrator manufactured by the $\mathrm{HACH}$ company immediately after samples collection (Table 1).

\section{Analytical methods}

The chemical analyses were measured at the laboratory of Beijing Research Institute of Uranium Geology (Table 1). K, Na, Mg and $\mathrm{Ca}$ were measured by 22.2 ion chromatogram using 883 Basic IC pulse ion chromatograph based on the Standard Test Method of Drinking Water-Metal Indicator (GB/T 5750.62006). $\mathrm{Cl}, \mathrm{F}, \mathrm{NO}_{3}$ and $\mathrm{SO}_{4}$ were analyzed by ion chromatogram using ICS-1100 ion chromatograph based on the Test Method of the Quality of Groundwater (DZ/T 0064.51-1993). $\mathrm{HCO}_{3}$ and $\mathrm{CO}_{3}$ were analyzed by titration method using AT-510 automatic titration analysis meter based on the Test Method of the Quality of Groundwater (DZ/T 0064.49-1993). Si were determined by plasma mass spectrometry using NexION300D plasma mass spectrometer based on the Test Method of the Quality of Groundwater (DZ/T 0064.80-1993). $\mathrm{H}_{2} \mathrm{SiO}_{3}$ was measured by spectrophotometer at the Laboratory of the Beijing Brigade of Hydrogeology and Engineering Geology. The concentration of $\mathrm{SiO}_{2}$ was calculated according to the concentration of $\mathrm{Si}$ and $\mathrm{H}_{2} \mathrm{SiO}_{3} . \delta^{2} \mathrm{H}$ and $\delta{ }^{18} \mathrm{O}$ were detected by zinc reduction method for hydrogen isotopes (DZ/T 0184.19-1997) and carbon dioxide--water equilibrium method for oxygen isotopes (DZ/T 0184.21-1997).

The saturation index (SI) value is the logarithm of the ratio of the ion activity product (IAP) to the equilibrium solubility product $(\mathrm{K})$ at sample temperature is described as:

$\mathrm{SI}=\log (\mathrm{IAP} / \mathrm{K})(1)$

The value of the saturation index (SI) indicates whether the solution is in a state of undersaturation (negative $\mathrm{SI}$ ), saturation (positive SI), or at the state of equilibrium $(\mathrm{SI}=0)$ with respect to a mineral (Lorah and Herman, 1988; Shen et al., 1993). The value of the saturation index with respect to anhydrite, aragonite, calcite, dolomite, gypsum and halite of the water samples were calculated with PHREEQC (Parkhurst and Appelo, 1999) and using $\mathrm{Aq}^{*} \mathrm{Qa}$ carbonate equilibria database to obtain their partial pressure of $\mathrm{CO}_{2}$ $\left(\mathrm{PCO}_{2}\right)$. The concentrations of the hydrochemical compositions of the water samples were checked by charge balance error (Freeze and Cherry, 1979). The absolute values of relative error calculated for all the water samples from the balance between cations and anions range from $0.06 \%$ to $1.7 \%$.

Table 1 Field data and chemical constituents of the hot water samples

\section{Results and discussions}

\section{Hydrochemical parameters}

The precipitation of travertine is controlled by many factors, which can be grouped into 4 primary fields: (1) hydrochemistry, (2) hydrodynamics, (3) microbiology and (4) depositional environment. Hydrochemical conditions are the most important factors affecting the deposition of travertine (Zhou et al., 2017). The hydrochemical factors of the hot springs mainly includes the concentrations of the major ions and $\mathrm{CO}_{2}$, the partial pressure of $\mathrm{CO}_{2}$ (Table 1), $\gamma \mathrm{Ca} / \gamma \mathrm{HCO}_{3}$ and $\gamma \mathrm{Mg} / \gamma \mathrm{Ca}$ (Table 2), the saturation index with respect to anhydrite, aragonite, calcite, dolomite, gypsum and halite (Table 3) and the concentration of $\mathrm{CaCO}_{3}{ }^{0}$ (Table 4).

\section{Hydrochemical constituents}

Pentecost (1999) proposed that the concentrations of $\mathrm{Ca}$ and $\mathrm{HCO}_{3}$ are the most important factors that affect the travertine deposition, since the travertine mainly consist of calcite $\left(\mathrm{CaCO}_{3}\right)$, and almost all of the travertine deposits contain more than $90 \%$ of calcium carbonate. Na concentrations of the Heinitang hot springs range from 165 to $185 \mathrm{mg} / \mathrm{L}$, and for the concentrations of $\mathrm{Ca}$ are in the range between 85 and $115 \mathrm{mg} / \mathrm{L}$ (Table 1). The concentrations of $\mathrm{K}$ and $\mathrm{Mg}$ are relatively low, ranging from 23 to $24 \mathrm{mg} / \mathrm{L}$ and from 8 to $26 \mathrm{mg} / \mathrm{L}$, respectively. Compared with water samples S2* and $\mathrm{S} 4 *$, the concentrations of $\mathrm{Na}$ and 
$\mathrm{K}$ in the water samples $\mathrm{S} 2$ and $\mathrm{S} 4$ are almost constant, Ca concentrations increase and $\mathrm{Mg}$ contents in the water samples $\mathrm{S} 2$ and $\mathrm{S} 4$ decrease (Fig. 5a). $\mathrm{HCO}_{3}$ is dominant in the anions of the water samples, and its concentrations are high and range from 780 to $800 \mathrm{mg} / \mathrm{L}$ (Fig. 5b). The concentrations of $\mathrm{SO}_{4}$ and $\mathrm{Cl}$ are relatively low (Fig. 5b). The concentrations of $\mathrm{SO}_{4}$ are lower than $1 \mathrm{mg} / \mathrm{L}$, and the concentrations of $\mathrm{Cl}$ range from 50 to $70 \mathrm{mg} / \mathrm{L}$ in the water samples. The concentrations of $\mathrm{HCO}_{3}, \mathrm{SO}_{4}$ and $\mathrm{Cl}$ are almost unchanged, indicating that there is no significant evaporation from the hot water or other sources of water supply. In addition, the concentrations of $\mathrm{F}$ in the water samples are relatively high $(3.8-5 \mathrm{mg} / \mathrm{L})$ (Fig. $5 \mathrm{c}$ ), which are much higher than the World Health Organization (WHO) maximum guideline value $(1.5 \mathrm{mg} / \mathrm{L})$. The $\mathrm{F}$ concentration in natural waters depends on such factors as temperature, $\mathrm{pH}$, presence or absence of complexing or precipitating ions and colloids, solubility of fluorine-bearing minerals, anion exchange capacity of aquifer materials ( $\mathrm{OH}$ for $\mathrm{F}$ ), the size and type of geological formations traversed by water, and the amount of time that water is in contact with a particular formation (Apambire et al., 1997). Minerals which have the greatest effect on the hydrogeochemistry of fluoride are fluorite, apatite, micas, amphiboles, certain clays and villiaumite. Fluorite is the main mineral controlling aqueous fluoride geochemistry in most environments. However, there are some notable exceptions in sedimentary basin environments (Chae et al., 2006).

Fig. 5. (a) Cations, (b) anions, (c) $\mathrm{F}$ concentrations, (d) TDS, (e) $\mathrm{CO}_{2}$ concentration and $\mathrm{PCO}_{2}$ of the Heinitang hot water samples, (f) the relationship between $\mathrm{pH}$ and $\mathrm{PCO}_{2}$.

As a measure of water salinity, the TDS may be affected by different lithologies and geochemical conditions (Pasvanoğlu, 2013). Relatively high TDS values of the hot springs in western Yunnan are common. The TDS values are above $750 \mathrm{mg} / \mathrm{L}$ in the Heinitang hot springs (Fig. 5d), indicating that the hot spring water undergoes a deep circulation and longer residence time.

In general, the precipitation of travertine on the earth's surface is described by the overall reaction (Dandurand et al., 1982):

$\mathrm{Ca}^{2+}+2 \mathrm{HCO}_{3}{ }^{-}-\mathrm{CaCO}_{3}(\mathrm{~s})+\mathrm{H}_{2} \mathrm{O}+\mathrm{CO}_{2}(\mathrm{~g})(2)$

In this reaction, $\mathrm{CaCO}_{3}$ does not deposit immediately when $\mathrm{CO}_{2}$ outgases or is consumed. Therefore, the solution loses $\mathrm{CO}_{2}$ according to the following reaction:

$\mathrm{H}^{+}+\mathrm{HCO}_{3}{ }^{-}-\mathrm{H}_{2} \mathrm{CO}_{3}-\mathrm{H}_{2} \mathrm{O}+\mathrm{CO}_{2}(\mathrm{~g})(3)$

Consequently, the $\mathrm{CaCO}_{3}$ becomes supersaturated gradually and precipitates:

$\mathrm{Ca}^{2+}+\mathrm{CO}_{3}{ }^{2-}-\mathrm{CaCO}_{3}(\mathrm{~s})(4)$

This shows that the rate of $\mathrm{CO}_{2}$-outgassing can affect the deposition of travertine. Outgassing of $\mathrm{CO}_{2}$ occurs during surface flow as the travertine-depositing hot springs reach equilibrium with the atmosphere, which contributes to the formation of travertine (Lorah and Herman, 1988; Liu et al., 1995). Jones et al. (2005) suggested that the precipitation of travertine was driven by rapid $\mathrm{CO}_{2}$ degassing of $\mathrm{CO}_{2}$-rich spring waters along the flow path of hot springs. The concentrations and the partial pressure of $\mathrm{CO}_{2}$ are high and show high variability in the Heinitang hot springs. The values of $\mathrm{CO}_{2}$ concentrations and partial pressure range from 20 to $80 \mathrm{mg} / \mathrm{L}$ and from 0.04 to $0.5 \mathrm{~atm}$, respectively (Fig. 5e). The calculated $\mathrm{PCO}_{2}$ values are significantly higher than that of the atmosphere $(0.04 \% \mathrm{~atm})$. The release of $\mathrm{CO}_{2}$ is not only controlled by $\mathrm{PCO}_{2}$, but also related to the flowing path, the flowing rate and the location of spring. As mentioned above, the deposition of travertine from hot spring vents S2, S3 and S4 stopped during a period of time, this can be caused by the decrease in discharge of the spring's vents. After the artificial construction of the pools, the spring waters flow along the wall of the pool, increasing the area in contact with the air and accelerating the releasing rate of $\mathrm{CO}_{2}$, which results in the deposition of travertine. This indicates that the high values of $\mathrm{CO}_{2}, \mathrm{PCO}_{2}$ and the conditions of $\mathrm{CO}_{2}$-outgassing are necessary factors for the precipitation of travertine from the hot springs.

$\mathrm{pH}$ of water is a common chemical parameter affecting the deposition of travertine, along with several other factors, such as the hydrochemical compositions of the water, temperature and $\mathrm{PCO}_{2}$ (Zhou et al., 2014). 
Shen et al. (1993) reported that $\mathrm{pH}$ values and $\mathrm{PCO}_{2}$ are not linearly related, but have a logarithmic relationship under the standard condition and equilibrium with respect to calcite in the solution. The observed values of $\mathrm{pH}$ of the water samples range from 6 to 8 and plot on the scatter diagram (correlation index $\mathrm{R}^{2}=0.9766$ ) (Fig. 5f). $\mathrm{pH}$ values can reflect the values of $\mathrm{PCO}_{2}$ to some degree.

Table 2 The ratios of $\mathrm{Ca}$ and $\mathrm{HCO}_{3}, \mathrm{Mg}$ and $\mathrm{Ca}$, and the hydrochemical type of the Heinitang hot spring “*” represents the water samples which were collected in 2013.

\section{Hydrochemical calculations}

Ratios of some components in hot water may have an effect on the deposition of travertine. The accumulation of bicarbonate content in the water tends to be limited to the concentration of calcium (Zhou et al., 2014). The ratios of $\gamma \mathrm{Ca} / \gamma \mathrm{HCO}_{3}$ in the water samples of the Heinitang hot spring are not significantly different. The value of $\gamma \mathrm{Ca} / \gamma \mathrm{HCO}_{3}$ in the water samples $\mathrm{S} 1, \mathrm{~S} 2, \mathrm{~S} 3, \mathrm{~S} 4$ and $\mathrm{S} 6$ is 0.44 , that in $\mathrm{S} 5$ is 0.43 and that in $\mathrm{S}^{*}$ and $\mathrm{S}^{*}$ is 0.35 (Fig. 6a).

Fig. 6. Ratios of $\gamma \mathrm{Ca} / \gamma \mathrm{HCO}_{3}$ (a) and $\gamma \mathrm{Mg} / \gamma \mathrm{Ca}$ (b)

This indicates that the value of $\gamma \mathrm{Ca} / \gamma \mathrm{HCO}_{3}$ in hot water cannot be used to determine whether the precipitation of travertine occurs or not. Apart from the value of $\gamma \mathrm{Ca} / \gamma \mathrm{HCO}_{3}, \quad \gamma \mathrm{Mg} / \gamma \mathrm{Ca}$ of hot springs is one of the important precipitation controlling factors, and precipitation of aragonite and calcite occurs easily when the value of $\gamma \mathrm{Mg} / \gamma \mathrm{Ca}$ exceeds 1 (Folk, 1994; Rossi and Lozano, 2016). The values of $\gamma \mathrm{Mg} / \gamma \mathrm{Ca}$ in S2* and $\mathrm{S}^{*}{ }^{*}$ water samples are 0.46 and 0.47 , respectively, and in other water samples the values are approximate 0.1 (Fig. 6b). They are significantly lower than 1. In addition, the precipitation of travertine also occurred near the Alhama-Jaraba hot spring in Spain when the values of $\gamma \mathrm{Mg} / \gamma \mathrm{Ca}$ were around 0.7 (Asta et al., 2017). This indicates that the factor of $\gamma \mathrm{Mg} / \gamma \mathrm{Ca}$ has little effect on the precipitation of travertine in the Heinitang and Alhama-Jaraba hot springs.

Precipitation of travertine easily occurs near the hot springs which are of $\mathrm{HCO}_{3}$-Ca type (Kpegli et al., 2015, Arenas et al., 2015). In an attempt to determine water types of the Heinitang hot springs in this paper, hydrochemical compositions of the water samples were plotted on the Piper diagrams (Piper, 1944). Concentration of carbonate is not plotted on the diagrams because of its low concentration in these water samples. All the water samples display a unique $\mathrm{HCO}_{3}-\mathrm{Ca} * \mathrm{Na}$ type (Fig. 7). The result shows that the water types of the travertine-depositing water samples and the water samples that do not deposit travertine are the same. This indicates that the water type of hot springs cannot be used to determine whether the precipitation of travertine occurs or not.

Fig. 7. Piper diagram showing the Heinitang hot spring samples.

\section{Phreeqc interactive calculation}

The saturation index with respect to calcite (SIc) can indicate that whether the precipitation of travertine may occur or not (Dilsiz, 2006). Minvielle et al. (2015) proposed that the saturation index with respect to calcite (SIc) is a significant parameter that can be used to study hydrochemistry of karst systems through calcium-carbonate equilibriums. The values of saturation index with respect to the anhydrite, aragonite, calcite, dolomite, gypsum and halite in the Heinitang hot springs are determined by Phreeqc Interactive 3.1.4 (Parkhurst and Appelo, 1999), and they are presented in Table 4.

Table 3 SI values with respect to minerals in the hot water samples.

The values of saturation index with respect to aragonite range from -0.41 to 0.99 . The values of saturation index with respect to calcite range from -0.29 to 1.11 . The values of saturation index with respect to dolomite range from -1.14 to 2.22. The SI values with respect to anhydrite and gypsum are similar and in the range from -4.1 to -3.6 . The SI values with respect to halite are the lowest and in the range of -7.48 to -6.59 (Table 3). The SI values with respect to aragonite, calcite and dolomite have the similar tendency, which are positive in water samples $\mathrm{S}^{*}, \mathrm{~S} 2, \mathrm{~S} 3, \mathrm{~S} 4^{*}$ and $\mathrm{S} 4$. The solution is in a state of saturation. However, the SI values with respect to aragonite, calcite and dolomite are negative for the S1, S5 and S6 water samples that 
almost not deposit travertine (Fig. 8). The results show that the SI values with respect to aragonite, calcite and dolomite can be affected by similar factors, and they are significant for the precipitation of travertine.

Fig. 8. SI values with respect to the anhydrite, aragonite, calcite, dolomite, gypsum and halite in the Heinitang hot spring samples.

As shown in Figure 8, compared with water samples $\mathrm{S}^{*}$ and $\mathrm{S} 4^{*}$, the SI values with respect to aragonite, calcite and dolomite decrease in water samples S2 and S4. The SI values with respect to aragonite and dolomite decrease from positive to negative. The SI values with respect to calcite decrease from 0.8 to 0.06 and from 1.11 to 0.1 , respectively. This indicates that the saturation index with respect to aragonite, calcite and dolomite can decrease with the precipitation of travertine from the hot spring. This may be the reason why travertine stops growing near these vents.

The main compositions of travertine are aragonite and calcite, and their molecular formulas are both $\mathrm{CaCO}_{3}$ (Pentecost, 2005). Based on the analyses above, it is clear that the concentration of calcium has a significant effect on the deposition of travertine. However, the concentration of calcium only represents the total calcium content, the concentration of free calcium and ion pairs of calcium are still unknown. Therefore, we want to know whether the concentrations of ion pairs of calcium have a significant effect on the precipitation of travertine. The main compositions of calcium include $\mathrm{Ca}, \mathrm{CaHCO}_{3}{ }^{+}, \mathrm{CaCO}_{3}{ }^{0}, \mathrm{CaSO}_{4}{ }^{0}, \mathrm{CaOH}^{+}$and $\mathrm{CaHSO}_{4}{ }^{+}$in the Heinitang hot spring. Shen et al. (1993) suggested that the total concentration of calcium can be calculated by:

$\mathrm{m}_{\mathrm{Ca}}(\mathrm{O})=\mathrm{m}_{\mathrm{Ca}}+\mathrm{m}_{\mathrm{CaHCO}_{3}^{+}}+\mathrm{m}_{\mathrm{CaCO}_{3}^{0}}+\mathrm{m}_{\mathrm{CaSO}_{4}^{0}}+\mathrm{m}_{\mathrm{CaOH}^{+}}+\mathrm{m}_{\mathrm{CaHSO}_{4}^{+}}$

where $\mathrm{m}$ represents molality, $\mathrm{O}$ refers to the total concentration.

The concentration of free calcium and ion pairs of calcium are calculated by Phreeqc Interactive 3.1.4 (Parkhurst and Appelo, 1999), and are listed in Table 4.

Table 4 Concentrations of the free calcium and ion pairs of calcium in the Heinitang hot spring.

As shown in Table 5, the concentration of free calcium $(\mathrm{Ca})$ is the highest in the water samples, with the concentration from 1.89 to $2.52 \mathrm{mmol} / \mathrm{L}$, and the concentrations of ion pair $\mathrm{CaHCO}_{3}{ }^{+}$and $\mathrm{CaCO}_{3}{ }^{0}$ range from 0.22 to $0.32 \mathrm{mmol} / \mathrm{L}$ and from 0.004 to $0.097 \mathrm{mmol} / \mathrm{L}$, respectively. Ion pair concentrations of $\mathrm{CaSO}_{4}{ }^{0}, \mathrm{CaOH}^{+}$and $\mathrm{CaHSO}_{4}{ }^{+}$are extremely low. The concentration of $\mathrm{CaSO}_{4}{ }^{0}$ ranges from $4.69 \times 10^{-4}$ to $1.13 \times 10^{-3} \mathrm{mmol} / \mathrm{L}$, the concentration of $\mathrm{CaOH}^{+}$, from $2.2 \times 10^{-7}$ to $6.56 \times 10^{-6} \mathrm{mmol} / \mathrm{L}$, and the concentration of $\mathrm{CaHSO}_{4}{ }^{+}$, from $3 \times 10^{-10}$ to $1.63 \times 10^{-8} \mathrm{mmol} / \mathrm{L}$. Therefore, the $\mathrm{CaSO}_{4}{ }^{0}, \mathrm{CaOH}^{+}$and $\mathrm{CaHSO}_{4}{ }^{+}$can be ignored, and only the free calcium $(\mathrm{Ca}), \mathrm{CaHCO}_{3}{ }^{+}$and $\mathrm{CaCO}_{3}{ }^{0}$ are considered.

The concentrations of $\mathrm{Ca}$ and $\mathrm{CaHCO}_{3}{ }^{+}$in the water samples collected in 2013 were relatively low. The concentrations of free calcium and $\mathrm{CaHCO}_{3}{ }^{+}$in the water samples collected in 2018 were relatively high, which were similar in all the water samples (S1, S2, S3, S4, S5 and S6) (Fig. 9a). However, the tendency of the $\mathrm{CaCO}_{3}{ }^{0}$ content in the water samples is completely different from those of $\mathrm{Ca}$ and $\mathrm{CaHCO}_{3}{ }^{+}$. The concentrations of $\mathrm{CaCO}_{3}{ }^{0}$ in the water samples collected in 2013 were significantly higher than those in the water samples collected in 2018. In addition, the concentrations of $\mathrm{CaCO}_{3}{ }^{0}$ in water samples $\mathrm{S} 2, \mathrm{~S} 3$ and $\mathrm{S} 4$ were relatively high, the concentrations of $\mathrm{CaCO}_{3}{ }^{0}$ were relatively low for water samples $\mathrm{S} 1, \mathrm{~S} 5$ and $\mathrm{S} 6$ (Fig. 9b). As mentioned above, the size of travertine in 2018 was significantly larger than that in 2013 near the hot spring vents S2 and S4. Therefore, it is known that the concentration of $\mathrm{CaCO}_{3}{ }^{0}$ decreases and the concentrations of $\mathrm{Ca}$ and $\mathrm{CaHCO}_{3}{ }^{+}$almost remain constant with the precipitation of travertine. This indicates that the deposition of travertine can be greatly affected by the concentration of $\mathrm{CaCO}_{3}{ }^{0}$, while the concentrations of $\mathrm{Ca}$ and $\mathrm{CaHCO}_{3}{ }^{+}$have little influence on the precipitation of travertine. The high concentration of $\mathrm{CaCO}_{3}{ }^{0}$ in the hot spring may be more conducive to the deposition of travertine.

Fig. 9. Concentrations of free $\mathrm{Ca}, \mathrm{CaHCO}_{3}{ }^{+}$(a) and $\mathrm{CaCO}_{3}{ }^{0}$ (b) of the Heinitang hot spring.

Figures 8 and 9 show that the higher the concentration of $\mathrm{CaCO}_{3}{ }^{0}$, the higher the saturation index with respect to calcite (SIc), aragonite (SIa) and dolomite (SId) wound be. However, they are not linearly 
related, but have an exponential relationship (Fig.10). The curve of $\mathrm{CaCO}_{3}{ }^{0}$-calcite, with a steep slope, is almost the same as $\mathrm{CaCO}_{3}{ }^{0}$-aragonite except the intercept. The curve of $\mathrm{CaCO}_{3}{ }^{0}$-dolomite is relatively flat with a higher intercept. The intercept represents the corresponding concentration of $\mathrm{CaCO}_{3}{ }^{0}$ when the saturation index with respect to calcite $\left(\mathrm{SI}_{\mathrm{C}}\right)$, aragonite $\left(\mathrm{SI}_{\mathrm{A}}\right)$ and dolomite $\left(\mathrm{SI}_{\mathrm{D}}\right)$ are 0 (the solution is in equilibrium with calcite, aragonite and dolomite). When the calcite, aragonite and dolomite in the solutions are in equilibrium, the corresponding concentrations of $\mathrm{CaCO}_{3}{ }^{0}$ are $0.008 \mathrm{mmol} / \mathrm{L}, 0.01 \mathrm{mmol} / \mathrm{L}$ and $0.012 \mathrm{mmol} / \mathrm{L}$ (Fig. 10), respectively. This indicates that with the increasing $\mathrm{CaCO}_{3}{ }^{0}$ concentration in the Heinitang hot spring, calcite first reaches the dissolution equilibrium compared with dolomite and aragonite.

In addition, the concentrations of $\mathrm{CaCO}_{3}{ }^{0}$ in water samples $\mathrm{S}^{*}$ and $\mathrm{S} 4 *$ collected in 2013 are higher than those of water samples S2 and S4 collected in 2018. The saturation index with respect to dolomite, calcite and aragonite are positive and the value of saturation index with respect to dolomite is significantly higher than those of calcite and aragonite, which may deposit firstly. However, with the precipitation of dolomite, the concentrations of $\mathrm{CaCO}_{3}{ }^{0}$ and the saturation index with respect to dolomite, calcite and aragonite wound decrease. Therefore, the values of saturation index with respect to dolomite and aragonite are negative in water samples S2 and S4. The value of saturation index with respect to calcite also decreases but is positive. The precipitation of active travertine consisting of calcite occurs in 2018. This indicates that the precipitation of travertine is affected by the deposition of $\mathrm{CaCO}_{3}{ }^{0}$. The relationship between the concentration of $\mathrm{CaCO}_{3}{ }^{0}$ and the saturation index with respect to dolomite, calcite and aragonite can be used to simply identify the composition of travertine. When the concentration of $\mathrm{CaCO}_{3}{ }^{0}$ is higher than 0.018 $\mathrm{mmol} / \mathrm{L}$, the travertine may consist of dolomite, calcite and aragonite, and the concentration of dolomite is higher than calcite and aragonite. When the $\mathrm{CaCO}_{3}{ }^{0}$ concentration is between 0.008 and $0.018 \mathrm{mmol} / \mathrm{L}$, calcite is the main component of travertine. When the concentration of $\mathrm{CaCO}_{3}{ }^{0}$ is lower than $0.008 \mathrm{mmol} / \mathrm{L}$, the precipitation of travertine will hardly occur near the hot spring's vents.

Fig. 10. Relationship between SIc, SIa, SId values and $\mathrm{CaCO}_{3}{ }^{0}$ in the hot water samples.

\section{Conclusions}

Hydrochemical characteristics of the water samples from the travertine-depositing vents and non-travetinedepositing vents in the Heinitang hot spring indicate that the precipitation of travertine deposits from the hot water is mainly affected by the concentration of $\mathrm{CaCO}_{3}{ }^{0}$ and concentrations of $\mathrm{CO}_{2}, \mathrm{PCO}_{2}$ and the conditions of $\mathrm{CO}_{2}$-outgassing, and the effect of $\gamma \mathrm{Mg} / \gamma \mathrm{Ca}$ and $\gamma \mathrm{Ca} / \gamma \mathrm{HCO}_{3}$ on the precipitation of travertine is not obvious. The deposition of travertine is significantly affected by $\mathrm{CaCO}_{3}{ }^{0}$. With the deposition of travertine, the concentration of $\mathrm{CaCO}_{3}{ }^{0}$ in hot springs decrease. When the concentration of $\mathrm{CaCO}_{3}{ }^{0}$ is higher than $0.018 \mathrm{mmol} / \mathrm{L}$, the travertine consists of dolomite, calcite and aragonite, and the concentration of dolomite is higher than those of calcite and aragonite. When the $\mathrm{CaCO}_{3}{ }^{0}$ concentration is between 0.008 and $0.018 \mathrm{mmol} / \mathrm{L}$, calcite is the main component of travertine. When the concentration of $\mathrm{CaCO}_{3}{ }^{0}$ is lower than $0.008 \mathrm{mmol} / \mathrm{L}$, the precipitation of travertine will hardly occur near the hot spring.

\section{Acknowledgements}

This work was supported by the Natural Science Foundation of China (41772261). The authors want to thank Dr. Xiaocui Wang and M.S. Mi Long, Yuhui Zheng, Ting Chen and Chao Song for their help in the field work.

\section{Data Availability Statement}

The data used to support the findings of this study are included within the article. 


\section{References}

Andreo B, Martín-Martín M, Martín-Algarra A (1999). Hydrochemistry of spring water associated with travertines. Example of the Sierra de la Alfaguara (Granada, southern Spain). Surface Geoscience 328(11): $745-750$.

Asta MP, Auqué LF, Sanz FJ, Gemeno MJ, Acero P, Blasco M, Garcia-Alix A, Gomez J, Delgado-Huertas A, Mandado J (2017). Travertines associated with the Alhama-Jaraba thermal waters (NE, Spain): Genesis and geochemistry. Sedimentary Geology 347: 100-116.

Acikel S, Ekmekci M (2016). Hydrochemical characterization of Pamukkale travertines, Denizli, Turkey, for remediative measures. Environmental Earth Sciences 75(22): 1456.

Apambire WB, Boyle DR, Michel FA (1997). Geochemistry, genesis, and health implications of fluoriferous groundwaters in the upper regions of Ghana . Environmental Geology 33: 13-24.

Bureau of Geology and Mineral Resources of Yunnan Province. (1990). Regional Geology of Yunnan Province. Geological Publishing House (Beijing). (in Chinese)

Chae GT, Yun ST, Kwon M J (2006). Batch dissolution of granite and biotite in water: Implication for fluorine geochemistry in groundwater. Geochemical Journal 40 (1): 95-102.

Chafetz HS, Utech NM, Fitzmaurice SP (1991) Differences in the delta ${ }^{18} \mathrm{O}$ and delta ${ }^{13} \mathrm{C}$ signatures of seasonal laminae comprising travertine stromatolites. Journal of Sedimentary Research 61(6): 1015-1028.

Dilsiz C, Marques JM, Carreira PMM (2004). The impact of hydrological changes on travertine deposits related to thermal springs in the Pamukkale area (SW Turkey). Environmental Geology 45(6): 808-817.

Dilsiz C (2006). Conceptual hydrodynamic model of the Pamukkale hydrothermal field, southwestern Turkey, based on hydrochemical and isotopic data. Hydrogeology Journal. 14(4): 562-572.

Dandurand JL, Gout R, Hoefs J, Menschel G, Schott J, Usdowski E (1982). Kinetically controlled variations of major components and carbon isotopes in a calcite-precipitating stream. Chemical Geology. 36(3-4), 299315.

Erdoğan Y (2011). Engineering properties of Turkish travertines. Scientific Research and Essays. 6(21): 4551-4566.

Fouke BW, Farmer JD, Des Marais DJ, Pratt L, Sturchio NC, Burns PC, Discipulo MK (2000). Depositional facies and aqueous-solid geochemistry of travertine-depositing hot springs (Angel Terrace, Mammoth Hot Springs, Yellowstone National Park, U.S.A.). Journal of Sedimentary Research. 70(3): 565-585.

Fouke BW (2011). Hot-spring Systems Geobiology: abiotic and biotic influences on travertine formation at Mammoth Hot Springs, Yellowstone National Park, USA. Sedimentology. 58(1): 170-219.

Fedoseev GS, Vorontsov AA, Orekhov AA (2017). Fossil travertines and quasi-travertine in the Minusa basin (West Siberia): structure, composition, and comparative analysis. Russian Geology \& Geophysics. 58(8): 922-934.

Frery E, Gratier JP, Ellouz-Zimmerman N, Deschamps P, Blamart D, Hamelin B, Swennen R (2017). Geochemical transect through a travertine mount: A detailed record of $\mathrm{CO}_{2}$-enriched fluid leakage from Late Pleistocene to present-day-Little Grand Wash fault (Utah, USA). Quaternary International. 437: 98-106.

Freeze RA, Cherry JA (1979). Groundwater: Englewood Cliffs, NJ: Prentice-Hall, 604P.

Folk RL (1994). Interaction between bacteria, nanobacteria, and mineral precipitation in hot springs of central Italy. Géographie Physique et Quaternaire. 48: 233-246.

Ford TD, Pedley HM (1996). A review of tufa and travertine deposits of the world. Earth-Science Reviews. 41(3-4): 117-175. 
Jones B, Renaut RW, Owen RB, Torfason H (2005). Growth patterns and implications of complex dendrites in calcite travertines from Lýsuhóll, Snæfellsnes, Iceland. Sedimentology, 52(6): 1277-1301.

Jones B, Peng X (2016). Mineralogical, crystallographic, and isotopic constraints on the precipitation of aragonite and calcite at Shiqiang and other hot springs in Yunnan Province, China. Sedimentary Geology. $345,103-125$.

Kele S, Demény A, Siklósy Z, Nemeth T, Toth M, Kovacs MB (2008) Chemical and stable isotope composition of recent hot-water travertines and associated thermal waters, from Egerszalók, Hungary: Depositional facies and non-equilibrium fractionation. Sedimentary Geology. 211(3): 53-72.

Kele S, Özkul M, Fórizs I, Gokgoz A, Baykara MO, Alcicek MC, Nemeth T (2011). Stable isotope geochemical study of Pamukkale travertines: New evidences of low-temperature non-equilibrium calcite-water fractionation. Sedimentary Geology. 238(1): 191-212.

Kawai T, Kano A, Hori M (2009). Geochemical and hydrological controls on biannual lamination of tufa deposits. Sedimentary Geology. 213(1-2): 41-50.

Li G, Robert R (1998). Hot-spring travertine facies and sequences, Late Pleistocene, Rapolano Terme, Italy. Sedimentology. 45(1): 163-180.

Lorah MM, Herman JS, (1988). The chemical evolution of a travertine-depositing stream: Geochemical processes and mass transfer reactions. Water Resources Research. 24(9): 1541-1552.

Liu, Z. H., Svensson, U., Dreybrodt, W., Yuan, D. X., Buhmann, D., (1995). Hydrodynamic control of inorganic calcite precipitation in Huanglong Ravine, China: Field measurements and theoretical prediction of deposition rates. Geochimica Et Cosmochimica Acta. 59(15): 3087-3097.

Liu, Y. P., Zhou, X., Fang, B., Zhou, H. Y, Yamanaka, T., (2012). A preliminary analysis of the formation of travertine and travertine cones in the Jifei hot spring, Yunnan, China. Environmental Earth Science. 66: $1887-1896$.

Minvielle, S., Lastennet, R., Denis, A., Peyraube, N., 2015. Characterization of karst systems using SIc$\mathrm{pCO}_{2}$, method coupled with PCA and frequency distribution analysis. Application to karst systems in the Vaucluse county (Southeastern France). Environmental Earth Sciences. 74(12): 7593-7604.

Naroa, G.I., Aitziber, S.B., Salvador,B., (2018). Paleoenvironmental and paleoclimatic interpretation of the stratigraphic sequence of Lezetxiki II Cave (Basque Country, Iberian Peninsula) inferred from small vertebrate assemblages. Quaternary Research, 90(1): 164-179.

Piper, A. M., (1944). A graphic procedure in the geochemical interpretation of water-analyses. Eos Transactions American Geophysical Union. 25(6): 27-39.

Pentecost, A., (1995a). The Quaternary travertine deposits of Europe and Asia Minor. Quaternary Science Reviews. 14(10): 1005-1028.

Pentecost, A., (1995b). Geochemistry of carbon dioxide in six travertine-depositing waters of Italy. Journal of Hydrology. 167(1-4): 263-278.

Pentecost, A., (1999). The origin and development of the travertines and associated thermal waters at Matlock Bath, Derbyshire. Proceedings of the Geologists Association. 110(3): 217-232.

Pentecost, A., (2005). Travertines. The Netherlands: Springer.

Parkhurst, D. L. and Appelo, C. A. J., (1999). User's guide to PHREEQC (Version 2)-a computer program for speciation, batch -reaction, one-dimensional transport and inverse geochemical calculations. U.S. geological. Survey Water Resources Investigations Report. 99-4259.

Pasvanoğlu, S., (2013). Hydrogeochemistry of thermal and mineralized waters in the Diyadin (Ağri) area, Eastern Turkey. Applied Geochemistry. 38(3): 70-81. 
Rossi, C., Lozano, R. P, (2016). Hydrochemical controls on aragonite versus calcite precipitation in cave dripwaters. Geochimica et Cosmochimica Acta. 192: 70-96.

Shen, Z. L., Zhu, W. H., Zhong, Z. S., (1993). Fundamentals of hydrogeochemistry. Geological Publishing House, Beijing, 5-15. (in Chinese)

Viles, H. A. and Goudie, A. S., (1990). Tufas, travertines and allied carbonate deposits. Progress in Physical Geography. 14(1): 19-41.

Veysey, J., Fouke, B. W., Kandianis, M. T., Schickel, T. J., Johnson, R. W., Goldenfeld, N., (2008). Reconstruction of water temperature, $\mathrm{pH}$, and flux of ancient hot springs from travertine depositional facies. Journal of Sedimentary Research. 78(1-2):69-76.

Wang, X. C., Zhou, X., Zhao, J. B., Zheng, Y. H., Song, C., Long, M., (2015). Hydrochemical evolution and reaction simulation of travertine deposition of the Lianchangping hot springs in Yunnan, China. Quaternary International. 374: 62-75.

Yesertener, C., Elhatip, H., (1997). Evaluation of Groundwater Flow by Means of Dye-Tracing Techniques, Pamukkale Thermal Springs, Western Turkey. Hydrogeology Journal. 5(4): 51-59.

Zhou, X., Hu, F. S., He, J. T., Wang, X. S., Fang, B., (2014). Introduction to Groundwater Sciences. $2^{\text {nd }}$ ed. Geological Publishing House, Beijing. (in Chinese.)

Zhou, X., Jin, X. M., Liang, S. H., Shen, Y., Zhang, H. M., (2017). Special Topics on Groundwater Sciences. $2^{\text {nd }}$ ed. Geological Publishing House, Beijing. (in Chinese) 


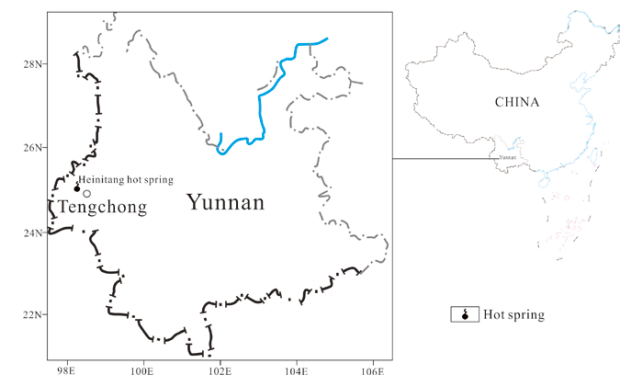

Fig. 1. The location of Yunnan and Tengchong (Adapted from National Geomatics center of China)

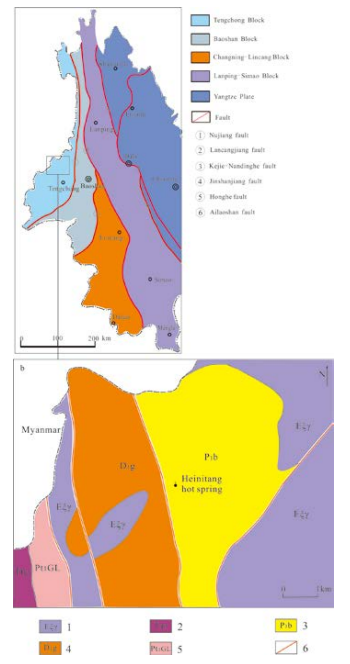

Fig. 2. (a) Simplified tectonic map of the area of western Yunnan and (b) the location of Heinitang hot spring (Adapted from Bureau of Geology and Mineral Resources of Yunnan Province, 1990) Legend: 1 Moyites of the Paleogene; 2 Monzonitic granite of the Triassic; 3 Sandstones of the Permian; 4 Argillic and carbonaceous slates of the Devonian; 5 Quartzites of the Proterozoic.

\section{Hosted file}

Figure.pdf available at https://authorea.com/users/351445/articles/476064-effect-ofhydrochemical-ion-pair-caco30-on-the-deposition-of-travertine-from-the-heinitang-hotsprings-in-yunnan-of-china 
Table 1

Field data and chemical constituents of the water samples

\begin{tabular}{cccccccccc}
\hline Item & $\mathrm{Unit}$ & $\mathrm{S} 1$ & $\mathrm{~S} 2 *$ & $\mathrm{~S} 2$ & $\mathrm{~S} 3$ & $\mathrm{~S} 4 *$ & $\mathrm{~S} 4$ & $\mathrm{~S} 5$ & $\mathrm{~S} 6$ \\
\hline Temperature & ${ }^{\circ} \mathrm{C}$ & 66.6 & 64 & 63.5 & 57.6 & 54.9 & 58.2 & 50.9 & 62.1 \\
Discharge & $\mathrm{L} / \mathrm{S}$ & 1 & $\mathrm{~N}$ & 0.3 & 0.2 & $\mathrm{~N}$ & 0.8 & 0.08 & 0.02 \\
$\mathrm{pH}$ & & 5.9 & 7.02 & 6.2 & 6.6 & 7.49 & 6.3 & 6 & 6.1 \\
$\mathrm{Eh}$ & $\mathrm{mV}$ & -6 & -70 & 12 & 24 & -33 & 102 & 44 & -6 \\
$\mathrm{CO}_{2}$ & $\mathrm{mg} / \mathrm{L}$ & 42.68 & 39.6 & 32.71 & 53.97 & 22 & 71.72 & 77.44 & 31.24 \\
$\mathrm{~F}$ & $\mathrm{mg} / \mathrm{L}$ & 3.95 & 5.08 & 4.47 & 4.58 & 5.03 & 4.04 & 4.01 & 3.88 \\
$\mathrm{Cl}$ & $\mathrm{mg} / \mathrm{L}$ & 53.2 & 67.7 & 54.7 & 54.7 & 67.5 & 57.7 & 53.9 & 52.2 \\
$\mathrm{SO}_{4}$ & $\mathrm{mg} / \mathrm{L}$ & 0.51 & 0.8 & 0.3 & 0.42 & 0.7 & 0.38 & 0.55 & 0.53 \\
$\mathrm{HCO}_{3}$ & $\mathrm{mg} / \mathrm{L}$ & 785 & 788.4 & 790 & 790 & 782.3 & 793 & 799 & 785 \\
$\mathrm{CO}_{3}$ & $\mathrm{mg} / \mathrm{L}$ & 0 & 0 & 0 & 0 & 0 & 0 & 0 & 0 \\
$\mathrm{Na}$ & $\mathrm{mg} / \mathrm{L}$ & 169 & 178 & 171 & 170 & 182 & 173 & 170 & 167 \\
$\mathrm{~K}$ & $\mathrm{mg} / \mathrm{L}$ & 23.8 & 23.8 & 23.9 & 23.8 & 24 & 24 & 23.9 & 23.4 \\
$\mathrm{Mg}$ & $\mathrm{mg} / \mathrm{L}$ & 8.73 & 25.6 & 9.06 & 9.04 & 25.3 & 8.53 & 9.02 & 8.8 \\
$\mathrm{Ca}$ & $\mathrm{mg} / \mathrm{L}$ & 112 & 92.6 & 114 & 113 & 88.8 & 114 & 112 & 112 \\
$\mathrm{TDS}^{2}$ & $\mathrm{mg} / \mathrm{L}$ & 764 & 387 & 772 & 771 & 371 & 778 & 773 & 760 \\
$\mathrm{SiO}_{2}$ & $\mathrm{mg} / \mathrm{L}$ & 63.8 & 73.3 & 67.5 & 68.2 & 73.9 & 63.2 & 65.4 & 65.4 \\
$p \mathrm{CO}_{2}$ & $\mathrm{~atm}$ & 0.60 & 0.12 & 0.44 & 0.24 & 0.04 & 0.38 & 0.46 & 0.47 \\
$\delta^{18} \mathrm{O}$ & $\% 0$ & -9.8 & -9.4 & -9.5 & -9.3 & -9.8 & -8.9 & -9.1 & -8.9 \\
$\delta^{2} \mathrm{H}$ & $\% 0$ & -67.5 & -74.4 & -65.3 & -66.5 & -76.5 & -63.9 & -64.3 & -67.1 \\
\hline
\end{tabular}

The symbol “*”” represents the water sample which was collected in 2013 .

Table 2

Estimated reservoir temperature using silica and cationic geothermometers and circulation depth of the Heinitang hot springs.

\begin{tabular}{cccccc}
\hline $\begin{array}{c}\text { Simple } \\
\text { ID }\end{array}$ & $\begin{array}{c}\text { Quartz } \\
\left({ }^{\circ} \mathrm{C}\right)\end{array}$ & $\begin{array}{c}\text { Chalcedony } \\
\left({ }^{\circ} \mathrm{C}\right)\end{array}$ & $\begin{array}{c}\text { Na-K } \\
\left({ }^{\circ} \mathrm{C}\right)\end{array}$ & $\begin{array}{c}\mathrm{K}-\mathrm{Mg} \\
\left({ }^{\circ} \mathrm{C}\right)\end{array}$ & $\begin{array}{c}\text { Circulation } \\
\text { depth }(\mathrm{m})\end{array}$ \\
\hline S1 & 113 & 84 & 232 & 63 & 1507 \\
S2* & 120 & 92 & 226 & 57 & 1671 \\
S2 & 116 & 87 & 231 & 63 & 1573 \\
S3 & 116 & 88 & 232 & 63 & 1584 \\
S4* & 120 & 92 & 225 & 57 & 1682 \\
S4 & 113 & 84 & 230 & 63 & 1495 \\
S5 & 114 & 85 & 232 & 63 & 1534 \\
S6 & 114 & 85 & 232 & 63 & 1534 \\
\hline \multicolumn{7}{r}{ The calculation results are retained as integers. The symbol “*” represents the water sample collected in 2013. }
\end{tabular}

\section{Hosted file}

Table.pdf available at https://authorea.com/users/351445/articles/476064-effect-ofhydrochemical-ion-pair-caco30-on-the-deposition-of-travertine-from-the-heinitang-hotsprings-in-yunnan-of-china 